\title{
Influence of lipid supplementation on milk components and fatty acid profile
}

\author{
Henrique Valentim Nunes Machado ${ }^{1 *}$, José Carlos Pereira ${ }^{2}$, Vitor Pereira Bettero ${ }^{3}$, Fernando \\ de Paula Leonel', Raphael Pavesi Araújo ${ }^{4}$, Leonardo Marmo Moreira ${ }^{1}$, Rafael Bastos Teixeira ${ }^{5}$, \\ Joanis Tilemahos Zervoudakis ${ }^{6}$
}

\footnotetext{
${ }^{1}$ Universidade Federal de São João del-Rei, Departamento de Zootecnia, São João del-Rei, MG, Brazil.

2 Universidade Federal de Viçosa, Departamento de Zootecnia, Viçosa, MG, Brazil.

${ }^{3}$ Vaccinar Nutrição e Saúde Animal, Belo Horizonte, MG, Brazil.

${ }^{4}$ Instituto Federal de Educação, Ciência e Tecnologia do Tocantins, Colinas do Tocantins, TO, Brazil.

${ }^{5}$ Instituto Federal de Minas Gerais, Bambuí, MG, Brazil.

${ }^{6}$ Universidade Federal de Mato Grosso, Cuiabá, MT, Brazil.
}

\begin{abstract}
The objective of this study was to evaluate the effects of different lipid sources in diets for lactating cows on milk yield and composition, conjugated linoleic acid (CLA) content, and fatty acid profile in the milk fat. Five primiparous Holstein cows were distributed in a $5 \times 5$ Latin square design. Treatments were: control (no lipid addition) and four other diets containing different lipids sources - ground raw soybean, cottonseed, soybean oil, and calcium salts of soybean fatty acids (CSSFA). The greater milk yield ( $\mathrm{kg} /$ day) and milk lactose $(\mathrm{g} / \mathrm{kg})$ and solids non-fat $(\mathrm{g} / \mathrm{kg})$ contents were obtained with the animals fed diets with CSSFA. Regarding the fatty acid profile in the milk fat, the diets with CSSFA and ground raw soybeans produced the greatest concentrations of polyunsaturated fatty acids and $\mathrm{C}_{18: 2}$. Supplementation with CSSFA provided a greater production ( $\mathrm{g} /$ day) of CLA, resulting in almost twice the values shown by the other treatments. The use of different lipid sources does not affect the milk total solids (protein, fat, and lactose) and CSSFA has a positive influence on the fatty acid profile of the milk fat and amount of CLA produced. Additionally, milk yield is not affected by this supplement.
\end{abstract}

Key Words: biohydrogenation, dairy production, fatty acids, supplementation

\section{Introduction}

There is a new utilitarian perspective to consider food in addition to its nutritive function. There is an increasing identification of the components of many foods with properties that are beneficial to humans. This fact shows a new way for research involving food science and animal science, among other correlated areas, such as the sector of functional foods (Roberfroid, 2002).

Thus, it is possible to detect functional aspects in products of animal origin and, consequently, provide expectations in terms of adding value to them, by making them differentiated and more attractive products. In this context, we can mention that milk composition includes

Received: April 13, 2016

Accepted: August 29, 2017

*Corresponding author: henriquemachado@ufsj.edu.br

http://dx.doi.org/10.1590/S1806-92902017001200006

How to cite: Machado, H. V. N.; Pereira, J. C.; Bettero, V. P.; Leonel, F. P.; Araújo, R. P.; Moreira, L. M.; Teixeira, R. B. and Zervoudakis, J. T. 2017. Influence of lipid supplementation on milk components and fatty acid profile. Revista Brasileira de Zootecnia 46(12):910-916.

Copyright (C) 2017 Sociedade Brasileira de Zootecnia. This is an Open Access article distributed under the terms of the Creative Commons Attribution License (http://creativecommons.org/licenses/by/4.0/), which permits unrestricted use, distribution, and reproduction in any medium, provided the original work is properly cited. a significant amount of conjugated linoleic acid (CLA). The CLA are trans fatty acids that have been the focus of studies demonstrating their beneficial action on the health of human beings, e.g., anticarcinogenic effect, increase in immune response, and assistance in the human development, among others (Wang and Jones, 2004).

Lipid supplementation to lactating cows shows a relevant potential to increase the milk CLA content, in addition to improving its fat profile (Glasser et al., 2008). In contrast, some lipid supplements may reduce the digestibility of other chemical fractions of the food, depending on the quality and quantity added to the diet (Palmquist et al., 2005).

There are many ways to supplement diet of cows with lipids. However, it is necessary to choose feedstuffs and their availability to the farmers. Besides, the price of the feedstuff is an important aspect to be considered.

Therefore, we chose ground raw soybeans, cottonseed, soybean oil, and calcium salts of soybean fatty acids as lipids sources, aiming to study their effects on fatty acid profile and conjugated linoleic acid content in milk.

\section{Material and Methods}

Five primiparous Holstein cows averaging $500 \pm 50 \mathrm{~kg}$ body weight (BW), with $100 \pm 20$ days of lactation, and 
milk yield of $25 \pm 4 \mathrm{~kg} /$ day were distributed in a $5 \times 5$ Latin square design. The animals were housed in individual stalls and feed was supplied twice daily, at 7:00 and 17:00 h. The animals received a total mixed ration.

The experiment lasted 105 days and each period consisted of 21 days, with the first 14 days used for adaptation and the other seven for data collection. The treatments were control (no lipid addition) and four other diets containing different lipid sources - ground raw soybean, cottonseed, soybean oil, and calcium salts of soybean fatty acids (CSSFA).

The five diets were adjusted to be isoproteic. It is important to notice that the four diets supplemented with lipid contained $5 \%$ of crude fat (Table 1 ).

The procedures described by AOAC (2000) were used to determine the dry matter (DM, method 967.03; AOAC, 1990), crude protein (CP, method 984.13; AOAC, 1990), and crude fat (CF, method 2003.06; Thiex et al., 2003). The neutral detergent fiber (NDF) was assayed with a heatstable amylase and expressed inclusive of residual ash (Van Soest et al., 1991). The concentration of non-fibrous

Table 1 - Balance, chemical composition, and some fatty acid contents in the experimental diets

\begin{tabular}{|c|c|c|c|c|c|}
\hline \multirow{2}{*}{ Ingredient $(\mathrm{g} / \mathrm{kg})$} & \multicolumn{5}{|c|}{ Experimental diet or treatment } \\
\hline & Control & SB & CS & $\mathrm{SO}$ & CSSFA \\
\hline Corn silage & 550.0 & 550.0 & 550.0 & 550.0 & 550.0 \\
\hline Grain corn & 247.0 & 240.0 & 210.0 & 250.0 & 250.0 \\
\hline Ground raw soybeans & 0.0 & 120.0 & 0.0 & 0.0 & 0.0 \\
\hline Soybean meal & 120.0 & 60.0 & 110.0 & 150.0 & 150.0 \\
\hline Calcium salts & 0.0 & 0.0 & 0.0 & 0.0 & 25.0 \\
\hline Cottonseed & 0.0 & 0.0 & 100.0 & 0.0 & 0.0 \\
\hline Soybean oil & 0.0 & 0.0 & 0.0 & 20.0 & 0.0 \\
\hline Urea/ammonium sulfate $(9: 1)$ & 13.0 & 10.0 & 10.0 & 10.0 & 10.0 \\
\hline Wheat bran & 50.0 & 0.0 & 0.0 & 0.0 & 0.0 \\
\hline $\mathrm{Na}$ bicarbonate/Mg oxide $(2: 1)$ & 4.0 & 4.0 & 4.0 & 4.0 & 4.0 \\
\hline Vitamins A-D-E mix & 1.0 & 1.0 & 1.0 & 1.0 & 1.0 \\
\hline Mineral mix ${ }^{1}$ & 15.0 & 15.0 & 15.0 & 15.0 & 10.0 \\
\hline
\end{tabular}

Chemical composition of the experimental diets ( $\mathrm{g} / \mathrm{kg}$ of dry matter)

$\begin{array}{lccccc}\text { Dry matter } & 587 & 593 & 592 & 589 & 588 \\ \text { Organic matter } & 936 & 936 & 936 & 934 & 934 \\ \text { Crude protein } & 159 & 160 & 158 & 157 & 157 \\ \text { Crude fat } & 33 & 54 & 50 & 51 & 53 \\ \text { Non-fibrous carbohydrates } & 382 & 361 & 348 & 376 & 373 \\ \text { Neutral detergent fiber } & 380 & 376 & 395 & 365 & 365\end{array}$

Some fatty acid contents in the experimental diets (g/100 g of crude fat)

\begin{tabular}{lccccc}
$\mathrm{C}_{14: 0}$ & 0.81 & 0.74 & 0.67 & 0.72 & 0.55 \\
$\mathrm{C}_{16: 0}$ & 16.44 & 14.46 & 18.62 & 13.89 & 12.93 \\
$\mathrm{C}_{18: 0}$ & 3.13 & 4.49 & 2.86 & 3.44 & 2.89 \\
$\mathrm{C}_{18: 1 \text { cis }}$ & 13.03 & 19.72 & 13.47 & 16.18 & 16.55 \\
$\mathrm{C}_{18: 2}$ & 31.70 & 37.27 & 40.29 & 37.65 & 35.59 \\
$\mathrm{C}_{18: 3}$ & 7.19 & 6.47 & 4.47 & 6.34 & 5.70 \\
Others & 3.13 & 2.04 & 3.66 & 3.89 & 4.00 \\
\hline
\end{tabular}

SB - ground raw soybeans; CS - cottonseed; SO - soybean oil; CSSFA - calcium salts of soybean fatty acids (Megalac- $E^{\circledR}$ ).

${ }^{1}$ Composition: $425 \mathrm{~g} / \mathrm{kg}$ dicalcium phosphate; $250 \mathrm{~g} / \mathrm{kg}$ limestone; $210 \mathrm{~g} / \mathrm{kg}$ common salt; $75 \mathrm{~g} / \mathrm{kg}$ potassium chloride; $25 \mathrm{~g} / \mathrm{kg}$ ammonium sulfate; $12.5 \mathrm{~g} / \mathrm{kg}$ zinc sulfate; $2.50 \mathrm{~g} / \mathrm{kg}$ copper sulfate; $0.15 \mathrm{~g} / \mathrm{kg}$ cobalt sulfate; $0.05 \mathrm{~g} / \mathrm{kg}$ sodium selenite. carbohydrates (NFC) was calculated as $\mathrm{OM}-(\mathrm{NDF}+\mathrm{CP}$ $+\mathrm{CF})$, in which $\mathrm{OM}=$ organic matter.

Cows were milked twice daily and milk yield was automatically recorded at each milking activity. Milk samples were taken on the third collection day of each experimental period at 6:00 and 16:00 h milking activities. Thus, a sample of approximately $300 \mathrm{~mL}$ was prepared, which was proportional to the yield in each milking, for the analyses of milk composition.

A 3.5\% fat-corrected milk (FCM) yield was estimated according to Sklan et al. (1992), using the following equation: $\mathrm{FCM}=(0.432+0.1625 \times \%$ milk fat $) \times$ milk yield in $\mathrm{kg} /$ day.

On the fourth day of each collection period, a $2 \%$ aliquot of the milk production was collected and frozen for the analysis of the fatty acid profile, following the methodology described by Feng et al. (2004). Aliquots of $30 \mathrm{~mL}$ were centrifuged at $17,800 \times \mathrm{g}$ for $20 \mathrm{~min}$ at $4{ }^{\circ} \mathrm{C}$ (Centrifuge Himac CR21, Hitachi Ltd., Katsuda, Japan), forming a supernatant milk cream ("fat cake") that was removed and frozen. Approximately $1 \mathrm{~g}$ of the fat cake was transferred to $1.5 \mathrm{~mL}$ Eppendorf ${ }^{\circledR}$ microtubes and centrifuged at $17,500 \times \mathrm{g}$ for $20 \mathrm{~min}$ at room temperature (Force 14 centrifuge-Denver Instrument Company, Denver, $\mathrm{CO}, \mathrm{USA}$ ). After centrifugation, the lipid fraction remained in the upper part of the tube, where it was collected with micropipettes and conditioned in 1-mL Eppendorf ${ }^{\circledR}$ tubes, which were frozen at $-10{ }^{\circ} \mathrm{C}$ until the preparation of the methyl esters.

The methyl esters were prepared using the method elaborated by Hartman and Lago (1986). Samples of $40 \mu \mathrm{L}$ of the fat were transferred to test tubes with screw caps. Lipids were hydrolyzed with the addition of $2.5 \mathrm{~mL}$ of the $\mathrm{NaOH}$ solution at $0.5 \mathrm{~N}$ in methanol under $70{ }^{\circ} \mathrm{C}$ for $15 \mathrm{~min}$ to obtain the methyl esters.

After chilling, $2 \mathrm{~mL}$ of $\mathrm{NaOH} 20 \%$ solution and $2 \mathrm{~mL}$ of hexane (HPLC grade) were added and then the tube was agitated by vortex so that approximately $1 \mathrm{~mL}$ of the upper phase containing the methyl esters was collected. Subsequently, another $1 \mathrm{~mL}$ of hexane (HPLC grade) was added to the tube, from which, again, approximately $1 \mathrm{~mL}$ of the upper phase was extracted. The methyl esters were stocked in amber-colored glass bottles and frozen at $-18{ }^{\circ} \mathrm{C}$ for later analyses.

Analyses of fatty acid methyl esters (FAME) in hexane from the milk fat were conducted in a gas chromatograph (GCMS-QP 5000 - Gas Chromatography Mass Spectrometer - Shimadzu, S.A., Kyoto, Japan) and the components of the methyl esters were separated in a Carbowax column $(30 \mathrm{~m} \times 0.25 \mathrm{~mm})$. 
The chromatography followed these conditions: injector temperature, $220{ }^{\circ} \mathrm{C}$; interface temperature, $240{ }^{\circ} \mathrm{C}$; gas flow in the column, $1.3 \mathrm{~mL} / \mathrm{min}$; column pressure, $67.7 \mathrm{kpa}$; linear velocity, $40.6 \mathrm{~cm} / \mathrm{s}$; outlet orifice, 3; injected volume, $1 \mu \mathrm{L}$; and carrier gas, helium (inert gas).

The identification of fatty acid peaks was performed by comparison with the retention times of fatty acids in a standard mixture of FAME (Supelco ${ }^{\mathrm{TM}}$ 37FAME Mix). The identification of specific CLA peaks was achieved by difference, comparing the retention times of the methyl esters from the mixture of conjugated fatty acids cis-9, trans -11 and trans -10 , cis-12 of a pure commercial product (05632 - SIGMA).

The statistical model was:

$$
\mathrm{Y}_{\mathrm{ijk}}=\mu+\gamma_{\mathrm{i}}+a_{\mathrm{j}}+\beta_{\mathrm{k}}+\mathrm{e}_{\mathrm{ijk}} \text {, }
$$

in which $\mu$ is the intercept, $\gamma_{i}$ corresponds to the effect of the $i$-th lipid supplement ( $\mathrm{i}=1$ to 5 ); $a_{\mathrm{j}}$ is the effect of the $j$-th animal $(\mathrm{j}=1$ to 5$) ; \beta_{\mathrm{k}}$ is the effect of the $k$-th experimental period ( $\mathrm{k}=1$ to 5$)$; and $\mathrm{e}_{\mathrm{ijk}}$ is the random error assumed iid $\mathrm{N}\left(0, \sigma^{2}\right)$. Treatments $\left(\gamma_{\mathrm{i}}\right)$ were considered as fixed effect; animals $\left(a_{j}\right)$, experimental period $\left(\beta_{\mathrm{k}}\right)$, and the error term $\left(\mathrm{e}_{\mathrm{ijk}}\right)$ are random effects. The data were subjected to analysis of variance and test of means, using the PROC MIXED procedure of SAS (Statistical Analysis System, version 9.0) with the command for repeated measures over time, applying Tukey's test for comparison of means and adopting the $5 \%$ level of confidence.

\section{Results}

There was no significant interaction between period and treatment in any of the studied variables. Milk fat, protein, lactose, total solids, and solids non-fat contents in grams per kilo did not show differences $(\mathrm{P}>0.05)$ in relation to the treatments (Table 2).

The average milk and lactose yield of animals receiving CSSFA were only greater than the productions of the cows fed the control and soybean oil diets. The animals that received the diet with ground raw soybeans and diet with cottonseed meal showed an intermediate performance, not differing $(\mathrm{P}>0.05)$ from the rest.

Regarding the production of solids non-fat, only the diet containing CSSFA and the control presented difference $(\mathrm{P}<0.05)$, being the higher value corresponding to the CSSFA-containing diet. All the other treatments showed an intermediate performance, not differing from the rest. The daily $3.5 \%$ of yield and the milk contents did not show differences $(\mathrm{P}>0.05)$ among the five diets (Table 2$)$.
The polyunsaturated fatty acid (PUFA) was the only one to present difference $(\mathrm{P}<0.05)$ among the treatments. The highest PUFA content was obtained with the milk from animals fed CSSFA and ground raw soybeans in relation to diets containing cottonseed and the control treatment. The diet containing soybean oil, however, was superior only to that containing cottonseed and the latter resulted in the milk with the lowest PUFA levels (Table 3). None of the other fatty acids was affected $(\mathrm{P}>0.05)$ by lipid supplementation.

When the fatty acids were analyzed individually, no effect of diet was observed for most of them. However, the fat in the milk produced from animals consuming cottonseed showed a higher $(\mathrm{P}<0.05)$ stearic acid $\left(\mathrm{C}_{18: 0}\right)$ content than the control treatment, whereas the other

Table 2 - Average values for daily yield and milk composition

\begin{tabular}{|c|c|c|c|c|c|c|c|}
\hline \multirow{2}{*}{ Variable } & \multicolumn{5}{|c|}{ Experimental diet or treatment } & \multirow{2}{*}{ SEM } & \multirow{2}{*}{ P-value } \\
\hline & Control & SB & $\mathrm{CS}$ & $\mathrm{SO}$ & $\overline{\text { CSSFA }}$ & & \\
\hline \multicolumn{8}{|c|}{ Composition (g/kg) } \\
\hline Fat & 37.8 & 31.9 & 37.7 & 37.4 & 33.1 & 0.22 & 0.187 \\
\hline Protein & 31.9 & 33.0 & 32.0 & 32.6 & 30.1 & 0.13 & 0.087 \\
\hline Lactose & 44.4 & 47.5 & 44.9 & 44.5 & 45.3 & 0.09 & 0.127 \\
\hline Total solids & 125.2 & 123.6 & 125.6 & 125.7 & 119.5 & 0.36 & 0.520 \\
\hline Solids non-fat & 87.4 & 91.8 & 88.0 & 88.4 & 86.4 & 0.21 & 0.098 \\
\hline \multicolumn{8}{|c|}{ Yield (kg/day) } \\
\hline Milk & $18.5 b$ & $19.9 \mathrm{ab}$ & $19.1 \mathrm{ab}$ & $18.7 \mathrm{~b}$ & $21.9 \mathrm{a}$ & 2.46 & 0.024 \\
\hline $3.5 \% \mathrm{FCM}$ & 19.3 & 18.2 & 19.8 & 19.5 & 21.2 & 2.42 & 0.423 \\
\hline Fat & 0.7 & 0.6 & 0.7 & 0.7 & 0.7 & 0.09 & 0.489 \\
\hline Protein & 0.6 & 0.6 & 0.6 & 0.6 & 0.7 & 0.06 & 0.264 \\
\hline Lactose & $0.8 b$ & $0.9 \mathrm{ab}$ & $0.9 \mathrm{ab}$ & $0.8 \mathrm{~b}$ & $1.0 \mathrm{a}$ & 0.11 & 0.008 \\
\hline Total solids & 2.3 & 2.4 & 2.4 & 2.4 & 3.6 & 0.27 & 0.272 \\
\hline Solids non-fat & $1.6 b$ & $1.8 \mathrm{ab}$ & $1.7 \mathrm{ab}$ & $1.7 \mathrm{ab}$ & $1.9 \mathrm{a}$ & 0.19 & 0.038 \\
\hline
\end{tabular}

SB - ground raw soybeans; CS - cottonseed; SO - soybean oil; CSSFA - calcium salt of soybean fatty acids $\left(\right.$ Megalac-E $\left.{ }^{\circledR}\right)$; SEM - standard error of the mean; FCM - fatcorrected milk

Means followed by the same letter in the row do not differ by Tukey's test at $5 \%$ significance.

Table 3 - Average values for milk fatty acid profile $(\mathrm{g} / \mathrm{kg}$ fat) separated by chain length and number of double bonds

\begin{tabular}{lccccccc}
\hline \multirow{2}{*}{ Variable } & \multicolumn{9}{c}{ Experimental diet or treatment } & \multirow{2}{*}{ SEM } & P-value \\
\cline { 2 - 6 } & Control & SB & CS & SO & CSSFA & & \\
\hline SCFA & 63.5 & 54.1 & 58.7 & 59.3 & 56.3 & 0.43 & 0.561 \\
MCFA & 545.5 & 490.4 & 513.7 & 505.5 & 490.5 & 2.51 & 0.439 \\
LCFA & 356.0 & 420.2 & 399.2 & 398.0 & 418.4 & 2.58 & 0.405 \\
OCFA & 31.7 & 31.0 & 29.1 & 29.3 & 26.1 & 0.15 & 0.191 \\
SFA & 715.4 & 677.6 & 718.0 & 692.6 & 659.6 & 2.20 & 0.299 \\
UFA & 279.4 & 315.3 & 277.4 & 299.0 & 333.3 & 2.15 & 0.298 \\
MUFA & 253.1 & 281.3 & 256.2 & 268.3 & 299.2 & 2.08 & 0.515 \\
PUFA & $26.1 \mathrm{bc}$ & $34.6 \mathrm{a}$ & $21.1 \mathrm{c}$ & $30.9 \mathrm{ab}$ & $33.9 \mathrm{a}$ & 0.22 & 0.000
\end{tabular}

SB - ground raw soybeans; CS - cottonseed; SO - soybean oil; CSSFA - calcium salts of soybean fatty acids (Megalac-E ${ }^{\circledR}$ ); SEM - standard error of the mean; SCFA - shortchain fatty acids; MCFA - medium-chain fatty acids; LCFA - long-chain fatty acid OCFA - odd-chain fatty acids; SFA - saturated fatty acid; UFA - unsaturated fatty acids; MUFA - monounsaturated fatty acids; PUFA - polyunsaturated fatty acids. Means followed by the same letter in the row do not differ by Tukey's test at $5 \%$ significance. 
treatments showed intermediate values. The highest linoleic acid $\left(\mathrm{C}_{18 \cdot 2}\right)$ content was detected in the milk from cows fed ground raw soybeans as compared with the control and the diet with cottonseed (Table 4).

The cows fed CSSFA produced higher CLA content in the milk fat than cows fed ground raw soybeans or cottonseed, but was not higher than cows in control or soybean oil treatments, which did not differ from the others. This same trend was observed for the amount of CLA per liter of milk (Table 4).

\section{Discussion}

The diet supplemented with CSSFA was efficient in increasing the milk yield in relation to the control and to supplementation with soybean oil. This is probably due to the lower availability (protection) of the unsaturated fatty acid contained in the CSSFA and to the ruminal processes of interaction with the microorganisms, including biohydrogenation. Thus, the smaller contact of the rumen microbes with the unsaturated fatty acid prevents toxic effects caused by these acids and, therefore, they do not affect the fiber digestibility and the microbial protein synthesis. Besides, the supplement also increases the energy density of the diet, which allows for increments in the milk yield.

Results of research studies are inconclusive in linking elevated milk yield to lipid supplementation, much less to some specific type of supplement. In this aspect, positive results for milk yield with fat-supplemented diets were obtained by Costa et al. (2007) and absence of responses by Eifert et al. (2006), Huang et al. (2008), and Ganjkhanlou et al. (2009).

The results obtained for $3.5 \%$ of FCM yield did not follow the same trend observed for milk yield. The greater production obtained with the treatment with CSSFA, when adjusted for $3.5 \%$ fat, became similar to the other treatments. This suggests that a smaller fat content in the milk produced by animals fed this supplement reduced the yield, resulting in this equality, although the milk fat concentrations did not show significant differences.

There is a great concern over the reduction of the milk total solid components, especially regarding the concentration of fat (Harvatine and Allen, 2005; AbuGhazaleh et al. (2003). In spite of this, in the present work, the lipid supplementation did not affect the milk fat. It probably happened because the lipid inclusion in the diet was not enough to promote the ruminal production of the trans-10, cis-12 CLA, and trans-10 18:1 to cause the syndrome of low milk fat content. These intermediate fatty acids have the greatest evidence of depressing the milk fat (Bauman and Griinari, 2003; Harvatine et al. 2009; Harvatine and Bauman, 2011).

Some researchers, among them Eifert et al. (2006) and Huang et al. (2008), observed a decrease in the fat content of milk produced by cows fed soybean oil. On the other hand,

Table 4 - Average values for milk fatty acid contents ( $\mathrm{g} / \mathrm{kg}$ fat)

\begin{tabular}{|c|c|c|c|c|c|c|c|}
\hline \multirow{2}{*}{ Fatty acid profile } & \multicolumn{5}{|c|}{ Experimental diet or treatment } & \multirow{2}{*}{ SEM } & \multirow{2}{*}{ P-value } \\
\hline & Control & SB & $\mathrm{CS}$ & SO & CSSFA & & \\
\hline $\mathrm{C}_{6: 0}$ & 26.8 & 24.3 & 27.0 & 26.7 & 27.7 & 0.13 & 0.369 \\
\hline $\mathrm{C}_{8: 0}^{0.0}$ & 15.0 & 10.7 & 12.1 & 12.0 & 9.3 & 0.21 & 0.430 \\
\hline $\mathrm{C}_{10: 0}^{80}$ & 36.6 & 29.4 & 27.9 & 33.2 & 27.8 & 0.25 & 0.122 \\
\hline $\mathrm{C}_{12: 0}$ & 44.1 & 35.5 & 32.6 & 39.7 & 3.5 & 0.27 & 0.076 \\
\hline $\mathrm{C}_{13: 0}^{120}$ & 1.1 & 0.9 & 0.8 & 0.9 & 0.8 & 0.00 & 0.080 \\
\hline $\mathrm{C}_{14: 0}^{1: 0}$ & 127.7 & 111.9 & 109.4 & 121.4 & 115.0 & 0.51 & 0.065 \\
\hline$C_{16: 0}$ & 310.4 & 288.5 & 321.1 & 287.2 & 290.6 & 1.71 & 0.418 \\
\hline $\mathrm{C}_{16.1}^{10.0}$ & 13.1 & 11.5 & 11.3 & 11.5 & 11.6 & 0.12 & 0.603 \\
\hline $\mathrm{C}_{17: 0}^{10.1}$ & 8.2 & 7.7 & 8.1 & 7.4 & 8.5 & 0.05 & 0.579 \\
\hline $\mathrm{C}_{17.1}$ & 1.7 & 1.1 & 1.9 & 1.4 & 1.6 & 0.03 & 0.310 \\
\hline $\mathrm{C}_{18: 0}^{1 / 1}$ & $101.6 \mathrm{~b}$ & $126.4 \mathrm{ab}$ & $139.3 \mathrm{a}$ & $123.1 \mathrm{ab}$ & $108.4 \mathrm{ab}$ & 0.85 & 0.030 \\
\hline $\mathrm{C}_{18: 1}^{18: 0}$ & 222.9 & 255.8 & 232.1 & 241.0 & 272.2 & 2.02 & 0.479 \\
\hline $\operatorname{CLA}(\mathrm{g} / \mathrm{L})$ & $0.13 \mathrm{ab}$ & $0.08 \mathrm{~b}$ & $0.08 \mathrm{~b}$ & $0.12 \mathrm{ab}$ & $0.19 \mathrm{a}$ & 0.02 & 0.015 \\
\hline
\end{tabular}

SB - ground raw soybeans; CS - cottonseed; SO - soybean oil; CSSFA - calcium salts of soybean fatty acids (Megalac-E ${ }^{\mathbb{1}}$ ); SEM - standard error of the mean; CLA - conjugated linoleic acid.

Means followed by the same letter in the row do not differ by Tukey's test at $5 \%$ significance.

${ }^{1}$ Isomers cis-9, trans-11 CLA and trans-10, cis-12 CLA. 
the results obtained in the present experiment corroborate Avila et al. (2000), Santos et al. (2001), and Ganjkhanlou et al. (2009), who did not find any effects of lipid supplements on the fat and protein contents of milk.

The lipid supplementation has a small effect on milk protein percentage (Linn, 1983; Palmquist and Jenkins, 1980) and when it happens, it is probably due to the inability of microorganisms to utilize lipids as a source of energy, impairing the microbial protein synthesis or by deficiency of glucose, as mentioned by Garnsworthy (2002). However, we did not find significant changes in this component, probably because the lipid inclusion was not enough to promote this process. Likewise, the lactose is the constant constituent in the milk, despite nutritional plan (Davies et al., 1983; Jenness, 1985). This can explain the lack of variation in the solids non-fat content of the milk.

The production of fat, protein, and total solids in $\mathrm{kg} / \mathrm{day}$ did not follow the values obtained for milk yield and remained equal for all treatments. Hence, a dilution effect could be suggested, since there was a higher milk yield for the treatment with CSSFA, characterizing a lower ratio between the milk components and milk yield, in $\mathrm{kg} / \mathrm{day}$. Yet, the concentrations as a percentage of these same components did not present differences (Table 2).

The lipid supplementation had no effect on short-chain fatty acids (SCFA), medium-chain fatty acids (MCFA), and long-chain fatty acids (LCFA) in the milk fat. The metabolic origin of these fatty acids can be useful to explain this. Fatty acids from $\mathrm{C}_{4}$ to $\mathrm{C}_{14}$ are originated from de novo synthesis within the cells of the mammary parenchyma, $\mathrm{C}_{16}$ arises from both diet and de novo synthesis, whereas LCFA $\left(>\mathrm{C}_{16}\right)$ derive from the absorption of circulating lipids (from the diet or from the mobilization of the body reserve) (Chilliard et al., 2000). The fatty acids containing six to 16 carbons could suffer reductions due to the inhibition of the de novo synthesis in the mammary gland by several trans 18 isomers, as reported by Shingfield and Griinari (2007). However, we did not observe this effect in present work, probably due to the lower amount of lipid supplements in the diet. Glasser et al. (2008) found a reduction in the value of these fatty acids, but they worked with animals that received higher levels of lipids in the diet than the animals in the present study (484 to $868 \mathrm{~g} /$ day versus approximately $380 \mathrm{~g} /$ day).

The CSSFA, soybean oil, and ground raw soybeans are feedstuffs rich in PUFA and are probably more resistant to the rumen biohydrogenation process, consequently resulting in greater PUFA escapes to the intestine to be incorporated in the milk fat. This is probably the cause of the highest PUFA values in milk fat of the cows that received these ingredients in the diets.

Regarding the fatty acid profile, the control diet resulted in the lowest $\mathrm{C}_{18: 0}$ content and the likely reason for this is the higher amount of LCFA contained in the lipid supplements utilized, which, depending on the extent of their biohydrogenation, produce stearic acid (Palmquist and Jenkins, 1980).

The fat of the milk from cows fed cottonseed had the highest and lowest values for $\mathrm{C}_{18: 0}$ and $\mathrm{C}_{18: 2}$, respectively. This happened because $\mathrm{C}_{18: 2}$ present in feeds are highly bio-hydrogenated in the rumen and the concentrations of these elements in the milk fat are not very affected when animals are supplemented with lipids, unless these lipids are protected (Glasser et al. 2008), like CSSFA in the present work (Table 4). A higher concentration of stearic acid in milk fat from cows supplemented with fat sources was also found by Huang et al. (2008) and by Weiss and Pinos-Rodríguez (2009).

The CSSFA supplement provided higher $(\mathrm{P}<0.05)$ CLA in milk than ground raw soybean and cottonseed (Table 4). Although not statistically significant, the CLA in milk fat of the cows which fed CSSFA was almost twice as much as the concentrations observed for cows fed the control and soybean oil diets. Regarding the ground raw soybeans and cottonseed supplements, the difference was significant, with CSSFA being responsible for an increase greater than $140 \%$ in the CLA content.

The physiological sources of CLA are biohydrogenation, in which CLA is intermediate, and the desaturation of vaccenic acid provoked by the activity of the $\Delta^{9}$-desaturase enzyme in the mammary gland. Thus, both CLA and trans-11 18:1, which escape the biohydrogenation process, are responsible for the deposition of CLA in the fat of cow milk (Palmquist, 2007; Jenkins at al., 2008). Consequently, protected lipid supplements or those that present traits favorable to greater ruminal passages of vaccenic acid and CLA to the intestine can be effective in increasing the milk CLA content (Harvatine and Allen, 2006), as is the case with CSSFA.

Several studies indicated that there was not a single lipid supplement responsible for supporting the increase in milk CLA (Huang et al., 2008; Boken et al., 2005; Harvatine and Allen, 2006; Mosley at al., 2006). However, there was one characteristic in common: these supplements should be rich in PUFA.

The CLA concentrations in the milk fat were also analyzed in $\mathrm{g} / \mathrm{L}$ of milk (Table 4), which showed the same trend as the contents of this fatty acid in the milk 
fat. Another result is the daily production of CLA in g/day, wherein both the concentrations of cis-9, trans-11 CLA in the fat and the milk yield obtained for the treatment with CSSFA were responsible for the greater quantity of CLA produced with this treatment.

\section{Conclusions}

The "protected" lipid (calcium salts of soybean fatty acids) shows a positive influence on the profile of fatty acids contained in milk fat, providing greater quantities ( $\mathrm{g} /$ day) of polyunsaturated fatty acids, especially in terms of conjugated linoleic acid. Ground raw soybeans promote an increase in the levels of polyunsaturated fatty acids in milk, but do not change the profile of conjugated linoleic acid. Cottonseed negatively modifies the milk fatty acid profile, increasing the content of saturated fatty acids. Soybean oil is not related to changes in the profile of milk fatty acids. Milk yield and milk composition are not affected by these supplements.

\section{References}

Abu-Ghazaleh, A. A.; Schingoethe, D. J.; Hippen, A. R. and Kalscheur, K. F. 2003. Milk conjugated linoleic acid response to fish oil supplementation of diets differing in fatty acid profiles. Journal of Dairy Science 86:944-953.

AOAC - Association of Official Analytical Chemists. 1990. Official methods of analysis of the Association of Official Analytical Chemists. 2 vols. 15th ed. Washington, DC.

AOAC - Association of Official Analytical Chemists. 2000. Official methods of analysis of AOAC International. 19th ed. Washington, D.C.

Avila, C. D.; Depeters, E. J.; Prez-Monti, H.; Taylor, S. J. and Zinn, R. A. 2000. Influences of saturation ratio of supplemental dietary fat on digestion and milk yield in dairy cows. Journal of Dairy Science 83:1505-1519.

Bauman, D. E. and Griinari, J. M. 2003. Nutritional regulation of milk fat synthesis. Annual Review of Nutrition 23:203-227.

Boken, S. L.; Staples, C. R.; Sollenberger, L. E.; Jenkins, T. C. and Thatcher, W. W. 2005. Effect of grazing and fat supplementation on production and reproduction of holstein cows. Journal of Dairy Science 88:4258-4272.

Chilliard, Y.; Ferlay, A.; Mansbridge, R. J. and Doreau, M. 2000. Ruminant milk fat plasticity: Nutritional control of saturated, polyunsaturated, trans and conjugated fatty acids. Annales de Zootechnie 49:181-205.

Costa, P. B.; Stumpf Junior, W.; Nörnberg, J. L.; Fischer, V.; Queiroz, A. C. and Mello, R. 2007. Suplementação de lipídeos de diferentes fontes em dietas para vacas Jersey na fase inicial de lactação. Revista Brasileira de Zootecnia 36:888-895.

Davies, D. T.; Holt, C. and Christie, W. W. 1983. The composition of milk. p.71-117. In: Biochemistry of lactation. Mepham, T. B., ed. Elsevier, Amsterdam.

Eifert, E. C.; Lana, R. P.; Lanna, D. P. D.; Teixeira, R. M. A.; Arcuri, P. B.; Leão, M. I.; Oliveira, M. V. M. and Valadares Filho, S. C. 2006. Perfil de ácidos graxos e conteúdo de ácido linoléico conjugado no leite de vacas alimentadas com a combinação de óleo de soja e fontes de carboidratos na dieta. Revista Brasileira de Zootecnia 35:1829-1837.

Feng, S.; Lock, A. L. and Garnsworthy, P. C. 2004. Technical note: A rapid lipid separation method for determining fatty acid composition in milk. Journal of Dairy Science 87:3785-3788.

Ganjkhanlou, M.; Rezayazdi, K.; Ghorbani, G. R.; DehghanBanadaky, M.; Morraveg, H. and Yang, W. Z. 2009. Effects of protected fat supplements on production of early lactation Holstein cows. Animal Feed Science and Technology 154:276-283.

Garnsworthy, P. C. 2002. Fat in dairy cow diets. p.399-444. In: Recent developments in ruminant nutrition 4. Nottingham University Press, Nottingham.

Glasser, F.; Ferlay, A. and Chilliard, Y. 2008. Oilseed lipid supplements and fatty acid composition of cow milk: A meta-analysis. Journal of Dairy Science 91:4687-4703.

Hartman, L. and Lago, L. C. A. 1986. Rapid separation of fatty acid methylesters. London: Laboratory practice 22:475-476.

Harvatine, K. J. and Allen, M. S. 2005. The effect of production level on feed intake, milk yield, and endocrine responses to two fatty acid supplements in lactating cows. Journal of Dairy Science 88:4018-4027.

Harvatine, K. J. and Allen, M. S. 2006. Effects of fatty acid supplements on milk yiel dand energy balance of lactating dairy cows. Journal of Dairy Science 89:1081-1091.

Harvatine, K. J.; Boisclair, Y. R. and Bauman, D. E. 2009. Recent advances in the regulation of milk fat synthesis. Animal 3:40-54.

Harvatine, K. J. and Bauman, D. E. 2011. Characterization of the acute lactational response to trans-10, cis-12 conjugated linoleic acid. Journal of Dairy Science 94:6047-6056.

Huang, Y.; Schoonmaker, J. P.; Bradford, B. J. and Beitz, D. C. 2008. Response of milk fatty acid composition to dietary supplementation of soy oil, conjugated linoleic acid, or both. Journal of Dairy Science 91:260-270.

Jenness, R. 1985. Biochemical and nutritional aspects of milk and colostrum. p.166-197. In: Lactation. Larson, B. L., ed. Iowa State University Press, Ames.

Jenkins, T. C.; Wallace, R. J. and Moate, P. J. and Mosley, E. E. 2008. Board-invited review: Recent advances in biohydrogenation of unsaturated fatty acids within the rumen microbial ecosystem. Journal of Animal Science 86:397-412.

Linn, J. G. 1983. The addition of fats to diets of lactating dairy cows: A review. In: Proceedings of a Feed Fat Seminar, sponsored by Central Bi-Products. Redwood Falls, Minn.

Mosley, E. E.; Shafii, B.; Moate, P. J. and McGuire, M. A. 2006. Cis- 9, trans-11 conjugated linoleic acid is synthesized directly from vaccenic acid in lactating dairy cattle. Journal of Nutrition $136: 570-575$.

Palmquist, D. 2007. Biohydrogenation then and now. European Journal of Lipid Science and Technology 109:737-739.

Palmquist, D. L.; Lock, A. L.; Shingfield, K. J. and Bauman D. E. 2005. Biosynthesis of conjugated linoleic acid in ruminants and humans. Advances in Food and Nutrition Research 50:179-217.

Palmquist, D. L. and Jenkins, T. C. 1980. Fat in lactation rations: Review. Journal of Dairy Science 63:1-14.

Roberfroid, M. B. 2002. Functional food concept and its application to prebiotics. Digestive and Liver Disease 34:105-110.

Santos, F. L.; Lana, R. P.; Silva, M. T. C.; Brandão, S. C. C. and Vargas, L. H. 2001. Produção e composição do leite de vacas submetidas a dietas contendo diferentes níveis e formas de suplementação de lipídios. Revista Brasileira de Zootecnia 30:1376-1380.

Shingfield, K. J. and Griinari, J. M. 2007. Role of biohydrogenation intermediates in milk fat depression. European Journal of Lipid Science and Technology 109:799-816. 
Sklan, D.; Ashkenazi, R.; Braun, A.; Devorin, A. and Tabori, K. 1992. Fatty acids, calcium soaps of fatty acids and cottonseeds fed to high yielding cows. Journal of Dairy Science 75:2463-2472.

Van Soest, P. J.; Robertson, J. B. and Lewis, B. A. 1991. Methods for dietary fiber, neutral detergent fiber, and nonstarch polysaccharides in relation to animal nutrition. Journal of Dairy Science 74:3583-3597.
Wang, Y. W. and Jones, P. J. 2004. Conjugated linoleic acid and obesity control: efficacy and mechanisms. International Journal of Obesityand Related Metabolic Disorders 28:941-955.

Weiss, W. P. and Pinos-Rodríguez, J. M. 2009. Production responses of dairy cows when fed supplemental fat in low-and high-forage diets. Journal of Dairy Science 92:6144-6155. 